стан близький до природного. Найбільш «чистими» та непорушеними масивами поверхневих вод, які можна розглядати як потенційні референційні є ділянки: Ріка та Раків (суббасейн Сяну); річка Білостік та озера Пулемецьке, Пісочне та Велике Піщанське в суббасейні Західного Бугу.

\title{
Література:
}

1. Методи гідроекологічних досліджень поверхневих вод / За ред. В.Д. Романенка. К.: Логос. 2006. 408 с.

2. Методика екологічної оцінки якості поверхневих вод за відповідними категоріями / В.Д. Романенко, В.М. Жукинський, О.П. Оксіюк та ін. К.: Символ-Т. 1998. 43 с.

3. Оцінка токсичності донних відкладів прісноводних об'єктів за допомогою біотестування / Гончарова М.Т., Кіпніс Л.С., Коновець I.М., Крот Ю.Г. Методичні рекомендації. Київ. 2019. 131 с.

4. Afanasyev S.O. Development of European approaches to biological assessment of the state of hydroecosystems and their application to the monitoring of Ukrainian Rivers. Hydrobiol. J. 2002. Vol. 38, N 4. P. 130-148.

DOI https://doi.org/10.30525/978-9934-26-006-3-16

\section{ОСНОВНІ АСПЕКТИ ЕКОЛОГІЧНОЇ ОСВІТИ ЗА СТАЛОГО РОЗВИТКУ В ОСВІТНЬОМУ ПРОЦЕСІ ЗВО}

\author{
Любинський О. I. \\ доктор сільськогосподарських наук, професор, \\ завідувач кафедри екологї
}

Кам'янеиь-Подільський національний університет імені Івана Огієнка м. Кам'янеиь-Подільський, Хмельницька область, Украйна

На початку третього тисячоліття в Україні відбувається становлення нової системи освіти, орієнтованої на входження до світового простору. Цей процес супроводжується історичними змінами в педагогічній теорії та практиці навчально-виховного процесу. Екологічна освіта, як цілісне культурологічне явище, повинна спрямовуватись на формування екологічної культури, екологізації навчальних дисциплін 
та програм підготовки, а також на професійну екологічну підготовку через базову екологічну освіту [3].

Екологічна освіта i виховання повинні орієнтуватись на активну взаємодію людини 3 природою, побудовану на науковій основі, на оцінюванні людини як частини природи. Екологічні знання, доповненні ціннісними орієнтаціями, повинні стати основою екологічної культури і екологічного мислення. Вони мають сприяти усвідомленню цінностей, допомагати вирішенню комплексних екологічних проблем, що стоять перед людством, забезпечити комфортність його проживання у майбутнього, зберегти та примножити унікальну різноманітність всієї біоти і зокрема рослинного та тваринного світу [6].

Проте глибина освітніх реформ, якість i ефективність роботи навчальних закладів і установ не можуть повною мірою задовольнити сучасні потреби особистості і суспільства. Негативним аспектом $є$ несформованість інституційного забезпечення впровадження концепції освіти в інтересах сталого розвитку [4].

Розв'язання сучасних екологічних проблем в Україні можливе тільки в умовах широкого й активного співробітництва зі всіма державами світу (особливо 3 державами-сусідами) у сфері екологічного права, екологічної політики та екологічної економіки [1].

Освіта $є$ найважливішою складовою суспільного, економічного життя країни, необхідною умовою їі стабільного розвитку. Без якісної освіти не можливі поступ держави у майбутнє, підготовка громадян до жит тя і праці у демократичному суспільстві, яке швидко змінюється і висуває дедалі зростаючі вимоги до рівня освіченості,вихованості молодого покоління. Загальносвітові й національні тенденції у сфері освіти визначають освіту як ключ до подолання бідності, запоруку громадянського миру та стрижень стратегії розвитку держави.

Концепція екологічної освіти України як елемент концепції гармонійного розвитку держави набуває сьогодні ваги актуального i важливого державного документа. Державна політика в галузі екологічної освіти повинна базуватися на таких принципах:

- розповсюдження системи екологічної освіти і виховання на всі верстви населення з урахуванням індивідуальних інтересів, стимулів та особливостей соціальних, територіальних груп та професійних категорій;

- комплексності екологічної освіти і виховання;

- неперервності процесу екологічного навчання в системі освіти, в тому числі підвищення кваліфікації та перепідготовки. 
Основною метою екологічної освіти $\epsilon$ формування екологічної культури окремих осіб і суспільства в цілому, формування навичок, фундаментальних екологічних знань, екологічного мислення і свідомості, що грунтуються на ставленні до природи як універсальної, унікальної цінності. В основу екологічної освіти покладені принципи гуманізму, науковості, неперервності, наскрізності та систематичності [2].

Найголовнішими завданнями екологічної освіти мають бути:

1. Формування екологічної культури всіх верств населення;

2. Підготовка фахівців-екологів для різних галузей народного господарства;

3. Удосконалення, узгодження і стандартизація термінології в галузі екологічних знань.

Стратегія сталого розвитку України повинна враховувати широкий спектр глобальних тенденцій, пов'язаних із ними ризиків і загроз на майбутне [4].

Гострою $є$ потреба у підготовці кадрів у сфері практичної екології, здатних вирішити нинішні соціально-екологічні проблеми і не допустити виникнення нових. Необхідно активізувати участь студентів у різноманітній дослідно - експериментальній, природоохоронній діяльності, організовувати екологічні клуби, гуртки, екологічні табори [5].

Якість освіти $є$ національним пріоритетом i передумовою національної безпеки країни, виконання міжнародних норм i національного законодавства щодо реалізації конституційних прав громадян України на здобуття якісної освіти. Забезпеченню якості освіти підпорядковуються матеріальні, фінансові, кадрові й наукою ресурси суспільства і держави, адрес на підтримка учнів та студентів. Висока якість освіти передбачає взаємозв'язок освіти i науки, педагогічної теорії та практики і ви значається на основі вимог стандартів освіти, оцінкою якості освітніх послуг суспільством. Держава спільно з громадськістю здійснює перманентний моніторинг якості освіти, забезпечує його прозорість, сприяє розвиткові громадського контролю.

Реалізація основних принципів екологічної освіти здійснюється у Кам'янець-Подільському національному університеті імені Івана Огієнка. Університет здійснює підготовку фахівців-екологів за першим (бакалаврським) та другим (магістерським) рівнем вищої освіти галузі знань 10 Природничі науки, спеціальності 101 Екологія за освітньопрофесійною програмою Екологія. Фундаментальну екологічну освіту отримують також майбутні біологи та географи. Окрім того, студенти педагогічного та економічного факультетів вивчають дисципліну 
«Основи екології / Екологія». В процесі викладання даної дисципліни враховується специфіка кожної спеціальності.

Викладачі природничого факультету проводять для вчителів та організаторів виховної роботи шкіл навчально-практичні семінари 3 тематичними екскурсіями на територію НПП «Подільські Товтри». На базі шкіл з екологічним спрямуванням організовують тренінги з метою вивчення рідкісних видів флори, фауни та біотопів, які потребують охорони як на національному так i на регіональному рівнях. Започаткований проект по створенню регіональної та локальної екологічних мереж, що сприятиме збереженню цінних природних об'єктів.

Впродовж останніх десяти років студенти і викладачі природничого факультету спільно 3 громадськими організаціями і працівниками національного природного парку «Подільські Товтри» та міського еколого-натуралістичного центру брали участь у семінарах, конференціях, а також проводили роз'яснювальну роботу щодо сортування побутових відходів. Кілька років підряд студентська молодь збирає й сортує сміття під час загальноміської акції «Триста спартанців», впроваджує акцію «Здай батарейку - збережи довкілля». Щороку громадська організація «Чисті схили» огранізовує екологічні акції щодо прибирання міста.

На природничому факультеті сформована Дружина охорони природи (ДОП). Дружина охорони природи - це молодіжна суспільна організація, що об'єднує людей (як правило студентів та випускників КПНУ ім. Огієнка), які бажають діяти для збереження Природи. Координатор роботи ДОП по факультету: Федорчук Іван Вікторович, кандидат біологічних наук, доцент кафедри екології. Також активно діє Кам'янець-Подільський міський осередок Міжнародної асоціації екологів університетів. Керівник осередку - доктор сільськогосподарських наук, професор, завідувач кафедри екології Любинський Олександр Іванович. Науково-педагогічні працівники кафедри $\epsilon$ діючими членами Кам'янець-Подільського місцевого відокремленого підрозділу НЕЦ України «НЕЦУ» «Зелені товтри». На базі кафедри екології діє «Школа молодого еколога».

Кафедра екології спільно з зарубіжними партнерами: Ivan Salamon, Assoc. Prof. (Slovak Academy of Science, Slovakia), Zbigniew Celka, Ph.D. (Department of Plant Taxonomy, Faculty of Biology, Adam Mickiewicz University, Poznań, Poland) видає «Вісник Кам'янець-Подільського національного університету імені Івана Огієнка. Серія Екологія». 
Щорічно проводяться екскурсії для студентів-першокурсників Кам'янець-Подільського національного університету імені Івана Огієнка у «Смотрицький каньйон», у Кам'янець-Подільський ботанічний сад загальнодержавного значення. Студентська молодь бере активну участь у практичних природоохоронних заходах i це сприяе розвитку відповідальності за стан довкілля, а також просуванню ідеї сталого розвитку.

\section{Література:}

1. Гордун I. М. Міжнародне співробітництво країн Центральної та Східної Європи з вирішення екологічних проблем / І. М. Гордун // Науковий вісник Волинського національного університету імені Лесі Українки // Национальная библиотека Украины имени В. И. Вернадського // http://www. nbuv. gov. ua.

2. Концепція екологічної освіти України затверджена Рішенням Колегії МОН України № 13 /6-19 від 20.12.01 // Міністерство освіти та науки України //www.mon.gov.ua

3. Курняк Л. М. Екологічне виховання студентів ВНЗ/ Л. М. Курняк, О. А. Курняк // Збірник наукових праць Хмельницького інституту соціальних технологій Університету «Україна». - 2012. № 5. - С. 109-114. - Режим доступу: http://nbuv.gov.ua/j-pdf/ Znpkhist_2012_5_26.pdf

4. Національна парадигма сталого розвитку України / за заг. ред. академіка Н-35 НАН України, д.т.н., проф., засл. діяча науки і техніки України Б. С. Патона. - К.: Державна установа «Інститут економіки риродокористування та сталого розвитку Національної академії наук України», 2012. - $72 \mathrm{c}$.

5. Онопрієнко В. екологічна освіта як предмет міжнародної співпраці// Вісник Інституту розвитку дитини. Вип. 14. Серія: Філософія, педагогіка, психологія: Збірник наукових праць. - Київ: Видавництво Національного педагогічного університету ім. М. П. Драгоманова, 2011. - С. 97-102.

6. Скиба Ю.А. Екологічна освіта як складова частина стратегії сталого розвитку // http://www.mama-86.org.ua/ecodemocracy/ skyba_u.htm. 